\title{
Sistem Informasi Keuangan Berbasis Web Untuk Pembayaran Uang Pendidikan Studi Kasus BMT Bening Suci Prambanan Yogyakarta
}

\author{
Raafiud Dwinata ${ }^{1,}$, Taufiq Ismail ${ }^{2}$ \\ Teknik Informatika Universitas Ahmad Dahlan, Jl. Ringroad Selatan, Bantul, Yogyakarta 55191, Indonesia \\ ${ }^{1}$ )raafiud12018181@webmail.uad.ac.id; ${ }^{2}$ taufiq@tif.uad.ac.id
}

\begin{abstract}
ABSTRAK
Sekolah merupakan sebuah lembaga tempat anak didik memperoleh pendidikan dan pelajaran diberikan guru. Salah satunya adalah sekolah yang ada dibawah yayasan PP Modern Baitussalam Bokoharjo Prambanan Yogyakarta meliputi, Taman Batita \& Kelompok Bermain Islam Terpadu (TB-KBIT), Taman Kanak-Kanak Islam Terpadu (TKIT) dan Sekolah Dasar Islam Terpadu (SDIT). Sama seperti sekolah-sekolah lain, sekolah tersebut terdapat administrasi berupa pembayaran uang pendidikan. Dalam melakukan pembayaran uang pendidikan, sekolah tersebut bekerjasama dengan Baitul Maal wat-Tamwil (BMT) Bening Suci. Baitul Maal wat-Tamwil (BMT) Bening Suci adalah sebuah lembaga ekonomi dan keuangan syariah yang berlokasi di Prambanan, Yogyakarta. BMT Bening Suci membutuhkan adanya suatu pengembangan sistem yang mampu melakukan pencatatan keuangan dan mencetak laporan. Di mana sistem akan mampu menginformasikan pencatatan keuangan di setiap melakukan transaksi pembayaran dan dapat mencetak laporan harian, bulanan dan tahunan dengan mudah.

Metodologi yang digunakan dalam penelitian ini yaitu melakukan pengumpulan data dari BMT Bening Suci Prambanan Yogyakarta, studi pustaka, dan wawancara langsung terhadap Kepala BMT Bening Suci Prambanan Yogyakarta. Metode pengembangan yang digunakan pada sistem ini menggunakan metode waterfall. Perancangan sistem ini menggunakan Behavior Diagram dan ERD, Implementasi menggunakan bahasa pemrograman PHP yang berbasis Framework Codeigniter dan MySQL sebagai manajemen database.

Sistem yang dihasilkan diuji dengan dua metode, yaitu Black Box Test dan Alpha Test. Hasil penelitian ini menghasilkan sistem informasi keuangan berbasis web. Pengujian dengan metode Black Box Test dihasilkan bahwa 100\% sistem sudah berjalan dengan baik, layak digunakan dan sesuai kebutuhan. Sedangkan pengujian dengan metode Alpha Test, responden mengatakan sebesar $11.25 \%$ "sangat setuju", sebesar $83.75 \%$ "setuju" dan 5\% "kurang setuju" bahwa sistem yang dibuat sudah berjalan dengan baik dan dapat membantu memberikan informasi pencatatan keuangan serta pelaporan keuangan.
\end{abstract}

Ciptaan disebarluaskan di bawah lisensi CC-BY-SA.

Kata kunci: SIK, Keuangan, SPP

\section{Pendahuluan}

Sekolah merupakan sebuah lembaga tempat anak didik memperoleh pendidikan dan pelajaran yang diberikan guru. Sekolah mempersiapkan anak didik memperoleh ilmu pengetahuan, keterampilan, budi pekerti, meningkatkan ketakwaan kepada Allah SWT agar selanjutnya mampu membekali diri menuju kearah pendidikan yang lebih tinggi sebagai bekal hidup di masyarakat. Salah satunya adalah sekolah yang ada dibawah yayasan PP Modern Baitussalam Bokoharjo Prambanan Yogyakarta yang memiliki sekitar 882 murid, meliputi Taman Batita \& Kelompok Bermain Islam Terpadu (TB-KBIT), Taman Kanak-Kanak Islam Terpadu (TKIT) dan Sekolah Dasar Islam Terpadu (SDIT. 
Sama seperti sekolah-sekolah lain, sekolah tersebut terdapat administrasi berupa pembayaran uang pendidikan. Dalam melakukan pembayaran uang pendidikan, sekolah tersebut bekerjasama dengan Baitul Maal wat-Tamwil (BMT) Bening Suci. Baitul Maal wat-Tamwil (BMT) Bening Suci adalah sebuah lembaga ekonomi dan keuangan syariah yang berlokasi di Prambanan, Yogyakarta.

Dalam pengolahan data transaksi BMT Bening Suci mengalami sedikit permasalahan karena masih menggunakan sistem yang kurang efektif. Pihak BMT Bening Suci menggunakan aplikasi spreadsheet dengan memasukkan data-data dan menghitung jumlah data transaksi pembayaran uang pendidikan satu per satu. Melihat potensi perkembangan usaha yang dimilikinya, pihak BMT Bening Suci merasa perlu untuk melakukan perubahan terhadap sistem yang selama ini berjalan. BMT Bening Suci merasa kesulitan dalam menangani basis data nasabahnya secara cepat, akurat dan efisien.

Melihat potensi perkembangan usaha yang dimilikinya, pihak BMT Bening Suci membutuhkan adanya suatu pengembangan sistem yang mampu melakukan pencatatan keuangan dan mencetak laporan. Dimana sistem akan mampu menginformasikan pencatatan keuangan di setiap melakukan transaksi pembayaran dan dapat mencetak laporan harian, bulanan dan tahunan dengan mudah.

Berdasarkan latar belakang diatas maka akan dibuat "Sistem Informasi Keuangan Berbasis Web untuk Pembayaran Uang Pendidikan Studi Kasus BMT Bening Suci Prambanan Yogyakarta". Diharapkan dengan pengembangan sistem ini memudahkan pihak BMT dalam melakukan pencatatan transaksi dan mencetak laporan.

\section{Kajian Pustaka}

Penelitian ini mengacu pada pada penelitian terdahulu [1]. Pada penelitian tersebut diungkapkan bahwa pengembangan sistem informasi keuangan, permasalahan yang terjadi yaitu sistem yang sedang berjalan masih dilakukan secara manual. Penelitian ini bertujuan untuk mempermudah pihak tata usaha dalam melakukan pembayaran dan laporan keuangan sekolah. Penelitian ini telah menghasilkan aplikasi yang cukup baik, terdapat fitur pembayaran dan pengolahan laporan keuangan sekolah.

Penelitian ini mengacu pada pada penelitian terdahulu [2]. Pada penelitian tersebut diungkapkan bahwa pengembangan sistem informasi keuangan pengelolaan keuangan sekolah, permasalahan yang terjadi yaitu kesalahan pencatatan dalam proses pengelolaan data khususnya bagian keuangan yang belum terkomputerisasi karena masih menggunakan pencatatan secara konvensional, yang mana petugas masih mencatat setiap rekapitulasi pembayaran siswa ke dalam sebuah buku besar atau buku kas. Penelitian ini bertujuan meminimalisasi adanya kesalahan dalam penginputan dan penyimpanan data serta mengoptimalkan keamanan data. Penelitian ini telah menghasilkan aplikasi yang cukup baik, terdapat fitur pengelolaan data pembayaran uang sekolah dan pengolahan laporan.

Berdasarkan kajian penelitian tersebut, maka dalam penelitian selanjutnya akan dibangun suatu Pengembangan Sistem Informasi Keuangan Berbasis Web untuk Pembayaran Uang Pendidikan di BMT Bening Suci Prambanan Yogyakarta. Sebagaimana layaknya sistem informasi keuangan pada umumnya, terdapat fitur umum pengelolaan data pembayaran uang pendidikan sekolah meliputi TB-KBIT, TKIT dan SDIT serta laporan pembayaran. Berbeda dengan sistem informasi keuangan pada penelitian sebelumnya, terdapat fitur khusus yaitu fitur tagihan untuk mengetahui pembayaran murid lunas atau belum lunas.

\subsection{Sistem Informasi}

Sesungguhnya, yang dimaksud dengan sistem informasi tidak harus melibatkan komputer. Sistem informasi yang menggunakan komputer bisa disebut sistem informasi berbasis komputer (Computer Based Information System atau CBIS). Dalam praktik, istilah sistem informasi lebih sering dipakai tanpa embel-embel berbasis komputer walau dalam kenyataannya komputer merupakan bagian penting [3].

\subsection{Framework}

\section{Definisi Framework}


Framework adalah sebuah struktur konseptual dasar yang digunakan untuk memecahkan sebuah permasalahan, bahkan isu-isu kompleks yang ada. Sebuah framework telah berisi sekumpulan arsitektur atau konsep-konsep yang dapat mempermudah dalam pemecahan sebuah permasalahan.

\section{Definisi Codeigniter}

Codeigniter adalah sebuah web aplikasi framework yang bersifat open source digunakan untuk membangun aplikasi php dinamis. Codeigniter menyediakan berbagai macam library yang dapat mempermudah dalam pengembangan. Codeigniter sendiri dibangun menggunakan konsep Model-View-Controller (MVC).

\section{Definisi MVC}

Model-View-Controller (MVC) adalah konsep dasar yang diketahui sebelum mengenal codeigniter. MVC adalah sebuah pattern atau teknik pemrograman yang memisahkan bisnis logic (alur piker), data logic (penyimpanan data) dan presentation logic (antarmuka aplikasi) atau secara sederhana adalah memisahkan antara desai, data dan proses [4].

\subsection{Basis Data}

Basis data adalah mekanisme yang digunakan untuk menyimpan informasi dan data. Informasi adalah sesuatu yang kita gunakan sehari-hari untuk berbagai alasan. Dengan basis data, pengguna dapat menyimpan data secara terorganisasi. Setelah data disimpan, informasi harus mudah diambil. Kriteria dapat digunakan untuk mengambil informasi. Cara data disimpan dalam basisdata menentukan seberapa mudah mencari informasi berdasarkan banyak kiteria. Data pun harus mudah ditambahkan ke dalam basisdata, dimodifikasi dan dihapus [5].

\section{Metodologi Penelitian}

\subsection{Subjek Penelitian}

Subjek penelitian ini adalah membangun Sistem Informasi Keuangan untuk pembayaran uang pendidikan di BMT Bening Suci Prambanan Yogyakarta. Sistem informasi Keuangan yang dibangun berbasis web.

\subsection{Metode Pengumpulan Data}

Dalam melakukan penelitian ini metode pengumpulan data yang dilakukan yakni menggunakan metode sebagai berikut:

1. Observasi

Metode observasi dilakukan dengan mengamati langsung ke tempat penelitian yaitu BMT Suci Bening. Pengamatan langsung ke tempat penelitian dilakukan untuk mengetahui proses yang terjadi. Obyek Observasi adalah petugas BMT yang mengelola sistem dan sistem yang digunakan. Data yang diperoleh adalah proses atau alur sistem yang berjalan di BMT.

2. Wawancara

Metode wawancara adalah metode pengumpulan data dengan cara tanya jawab secara langsung terhadap pihak yang berhubungan dengan sistem. Dalam hal ini adalah petugas BMT. Data yang diperoleh yaitu proses bisnis yang terjadi ketika melakukan pembayarn uang sekolah.

3. Studi Pustaka

Metode ini dilakukan dengan membaca literatur berupa buku, makalah, jurnal, artikel, termasuk pula pustaka-pustaka digital dari hasil browsing di internet yang berhubungan dengan penelitian ini.

\subsection{Alat Penelitian}

Alat penelitian yang digunakan dalam melakukan pengembangan sistem adalah:

1. Perangkat Keras (Hardware) berupa: Laptop Acer (Aspire E1 -571G) dengan spesifikasi processor Intel @ Core TM i3-2328M CPU @ 2.20GHz RAM 4 GB DDR 3 Hardisk 500GB, Printer dan Mouse

2. Perangkat Lunak (Software) berupa: sistem oprasi (windows), Bahasa pemrograman (Javascript, HTML, CSS, PHP Framework) dan Case Tool (Sublime Text, Ms Visio, Astah, Web Browser, Gui Design Studio). 


\subsection{Langkah-Langkah Pengembangan Sistem}

Dalam pengembangan sistem digunakan metode waterfall dimana dimulai dengan tahap sebagai berikut:

1. Analisis sistem

Mengidentifikasi masalah, mengidentifikasi kebutuhan fungsional, mengidentifikasi kebutuhan non fungsional, memodelkan dan menyatakan fungsi atau layanan yang disediakan (Use Case Diagram).

2. Perancangan

Perancangan Behaviour Diagram (Activity Diagram), Perancangan ERD (Entity Relational Diagram) Perancangan Database, dan Perancangan Interface.

3. Implementasi dan Pengujian Implementasi dengan pekodean (coding), melakukan pengujian menggunakan Black Box Test dan Alpha Test.

\section{Hasil dan Pembahasan}

\subsection{Analisis Kebutuhan User}

\subsubsection{Hak Akses Admin}

1. Proses login kedalam sistem

2. Mengolah data murid

3. Mengolah data pembayaran

4. Mengolah data laporan

\subsection{Data Flow Diagram}

Use case diagram digunakan untuk menggambarkan secara ringkas siapa yang menggunakan sistem dan apa saja yang bisa dilakukannya.

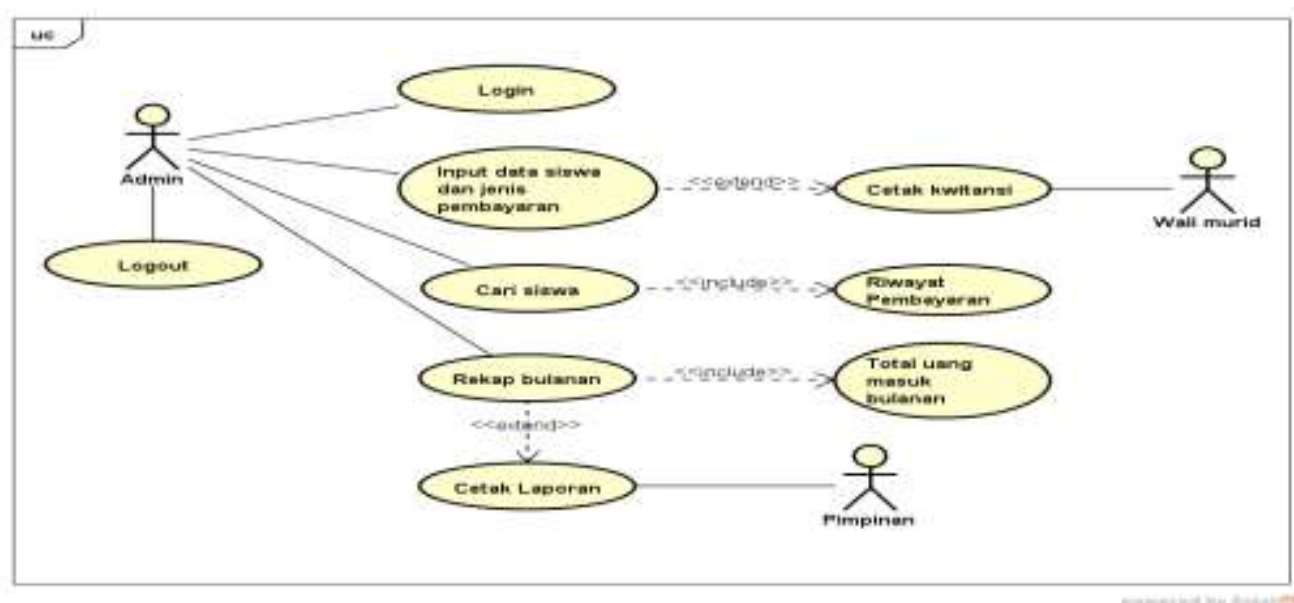

Gambar 1. Use Case Diagram

Dari Gambar 1 Use Case Konteks di atas dapat dijelaskan bahwa yang terlibat di dalam sistem yaitu:

1. Admin

Admin merupakan petugas BMT Bening Suci yang diberikan tugas untuk bertindak mengelola dan mengorganisasi data murid yang ada di dalam sistem.

2. Pimpinan

Pimpinan yang dapat memperoleh cetak laporan.

3. Wali Murid

Wali murid yang dapat memperoleh cetak kwitansi. 


\subsection{Entity Relationship Diagram}

Entity Reletionship Diagram (ERD) digunakan untuk merancang desain data dan menggambarkan hubungan antar data.

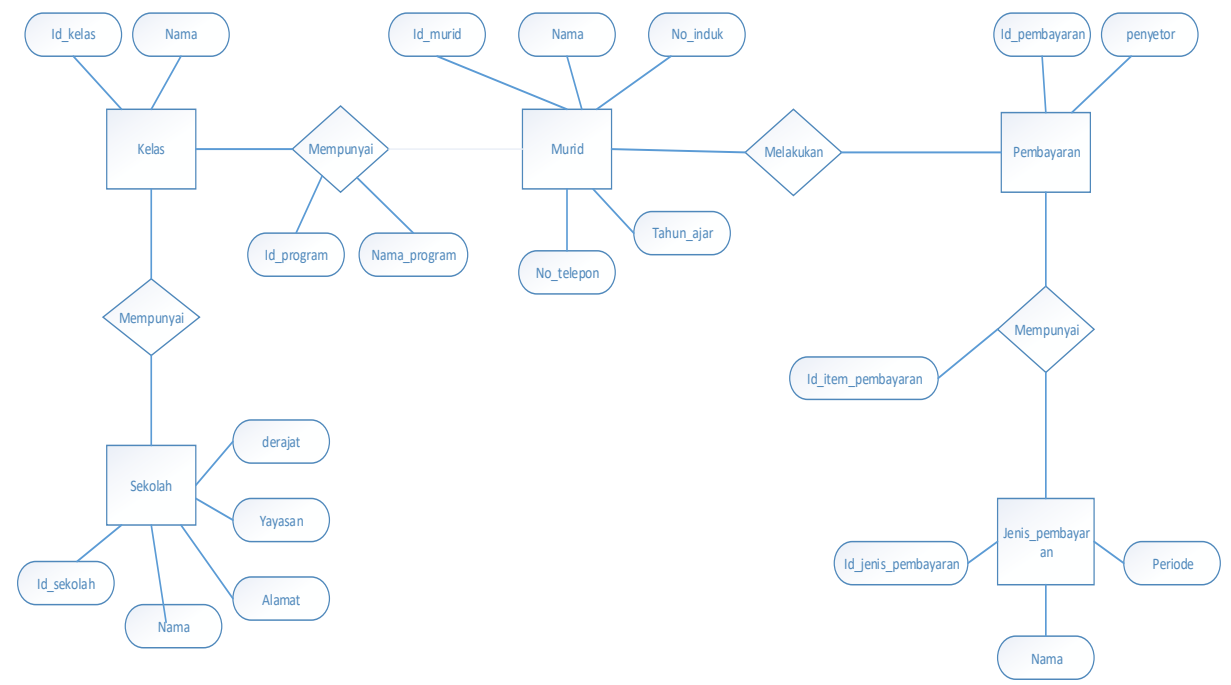

Gambar 2. Entity Relationship Diagram

\subsection{Implementasi}

Halaman Admin

1. Halaman Menu Kelas

Halaman menu kelas digunakan untuk menginputkan dan menampilkan tabel kelas untuk SD, TK, TB dan KB pada yayasan Baitussalam.

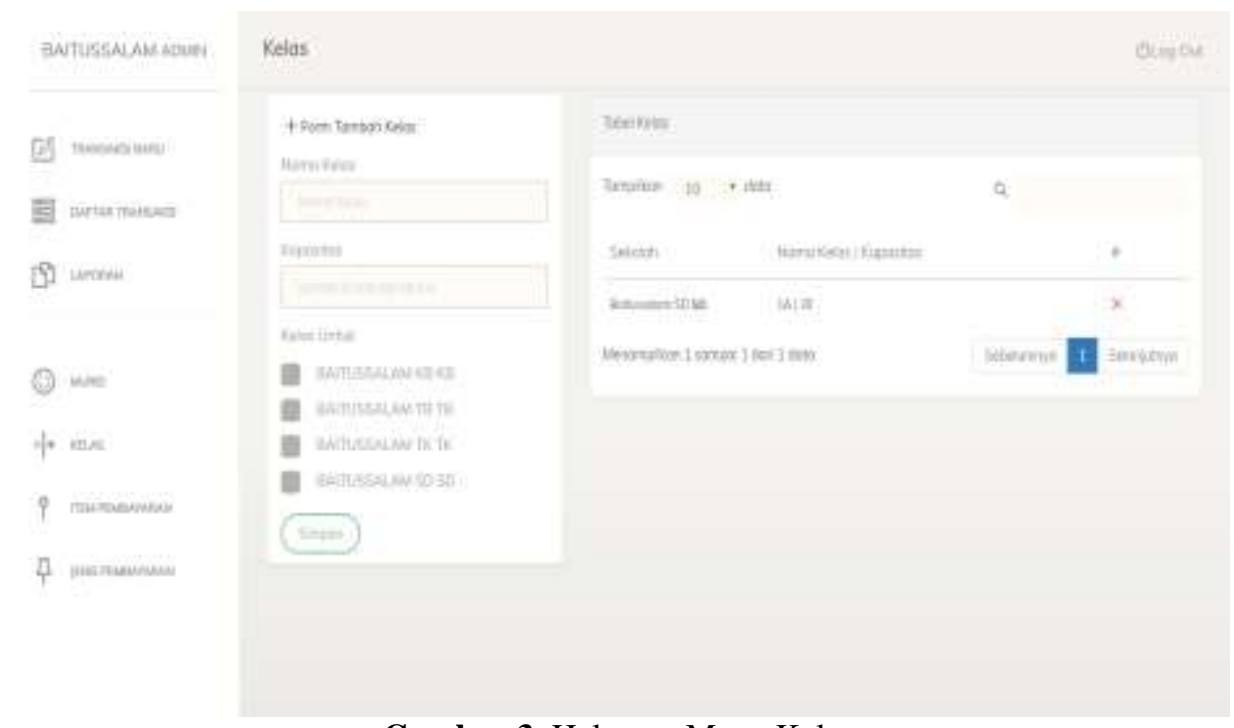

Gambar 3. Halaman Menu Kelas

2. Halaman Menu Murid

Halaman menu murid digunakan untuk menambah, mengedit dan menghapus data murid. 


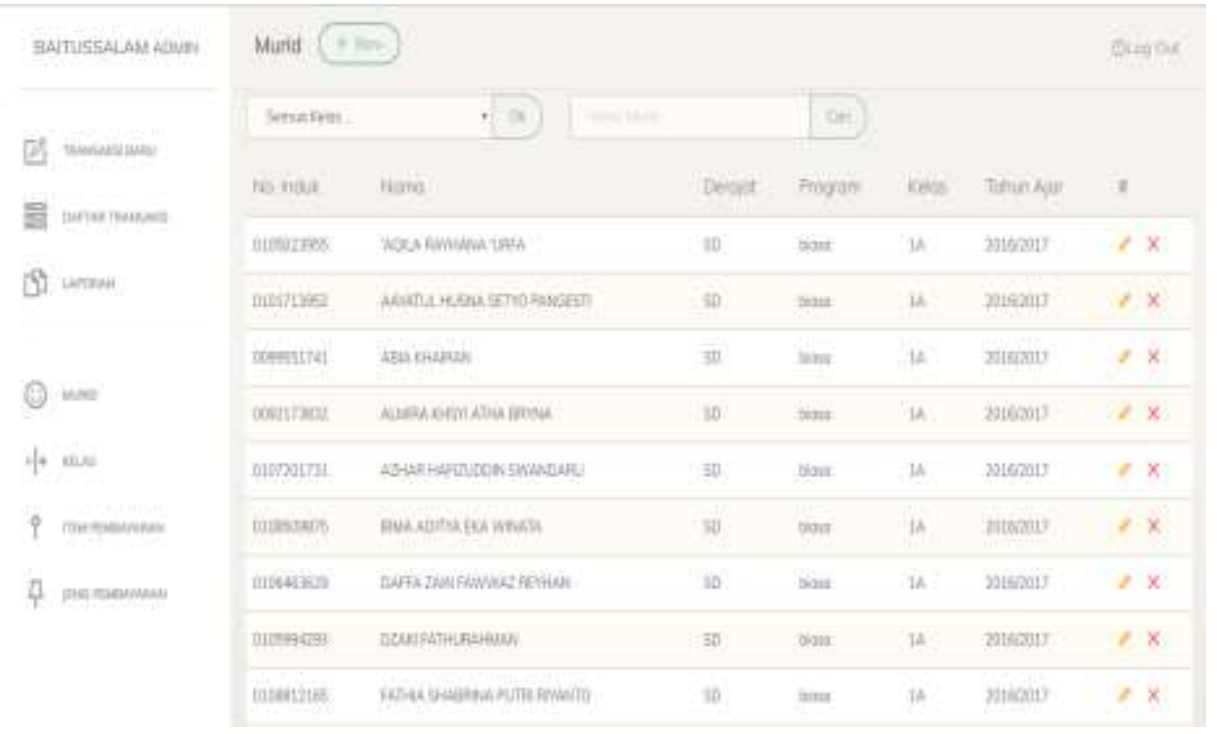

Gambar 4. Halaman Menu Murid

\section{Halaman Menu Jenis Pembayaran}

Halaman menu jenis pembayaran digunakan untuk menginputkan, mengedit, menghapus dan menampilkan nama jenis pembayaran.

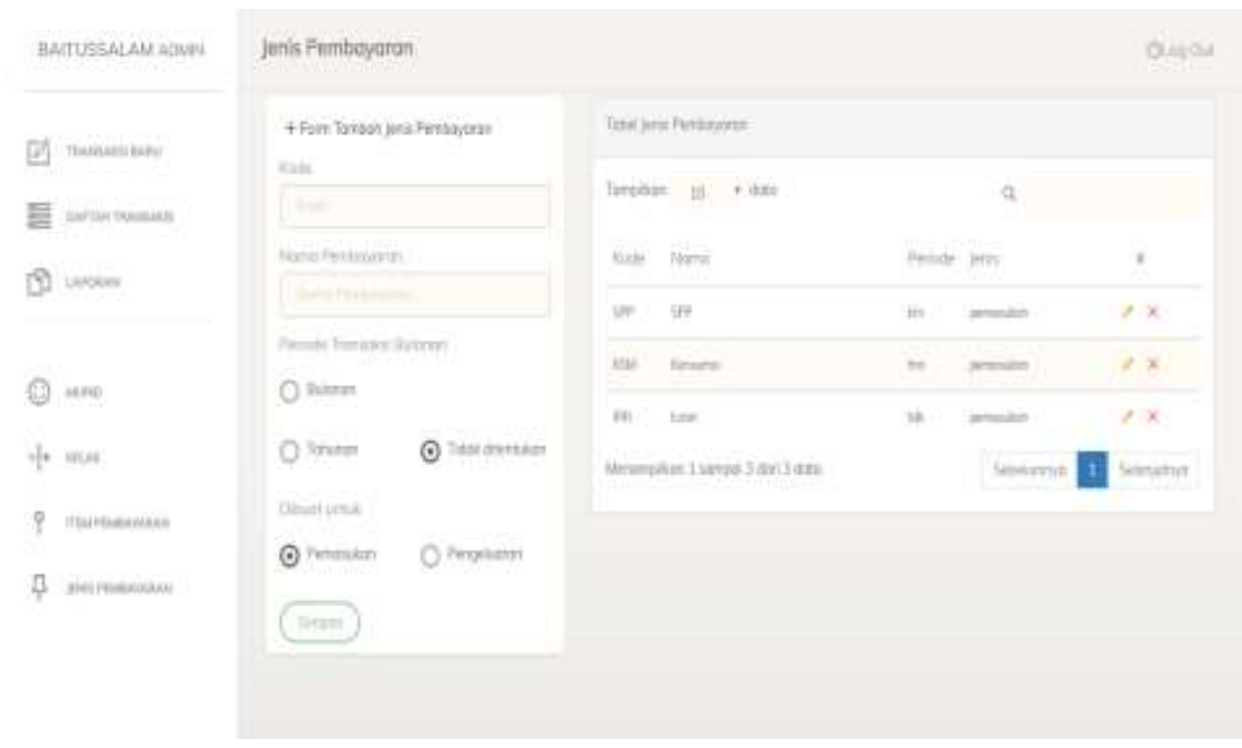

Gambar 5. Halaman Jenis Pembayaran

4. Halaman Menu Item Pembayaran

Halaman menu item pembayaran digunakan untuk memilih program dan batas jumlah harga yang harus dibayarkan. 


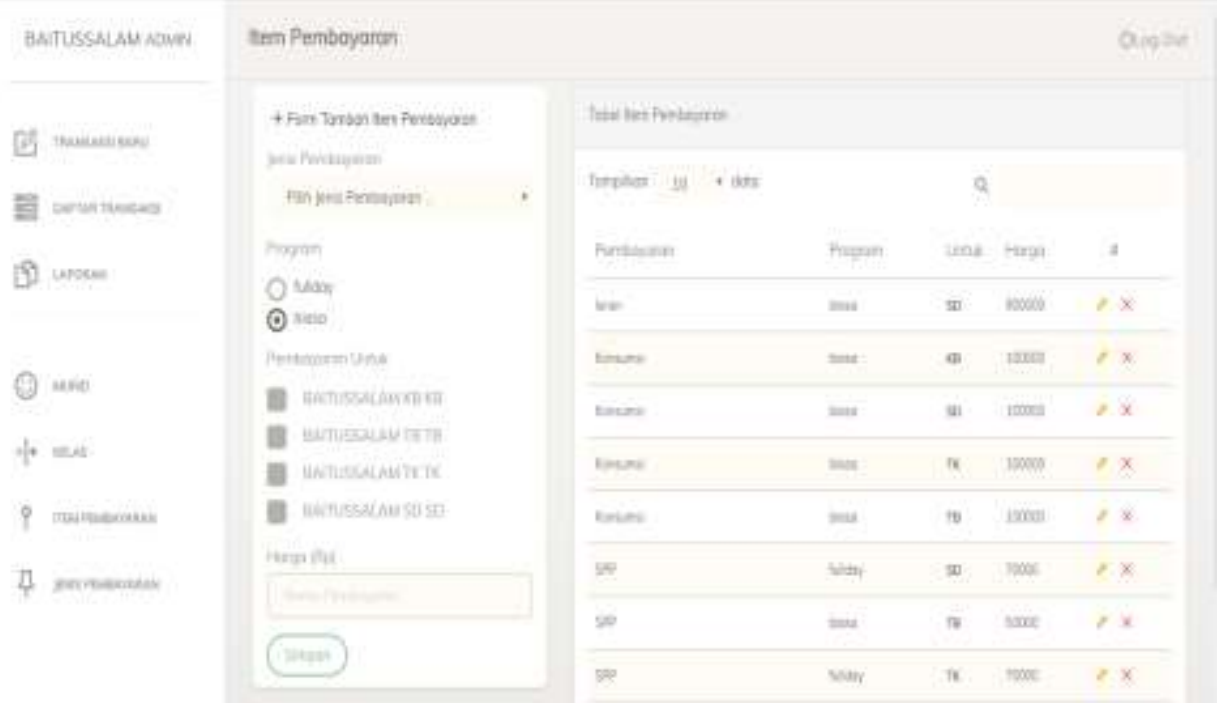

Gambar 6. Halaman Menu Item Pembayaran

5. Halaman Menu Pembayaran

Halaman menu pembayaran digunakan untuk menginputkan transaksi pembayaran uang pendidikan.

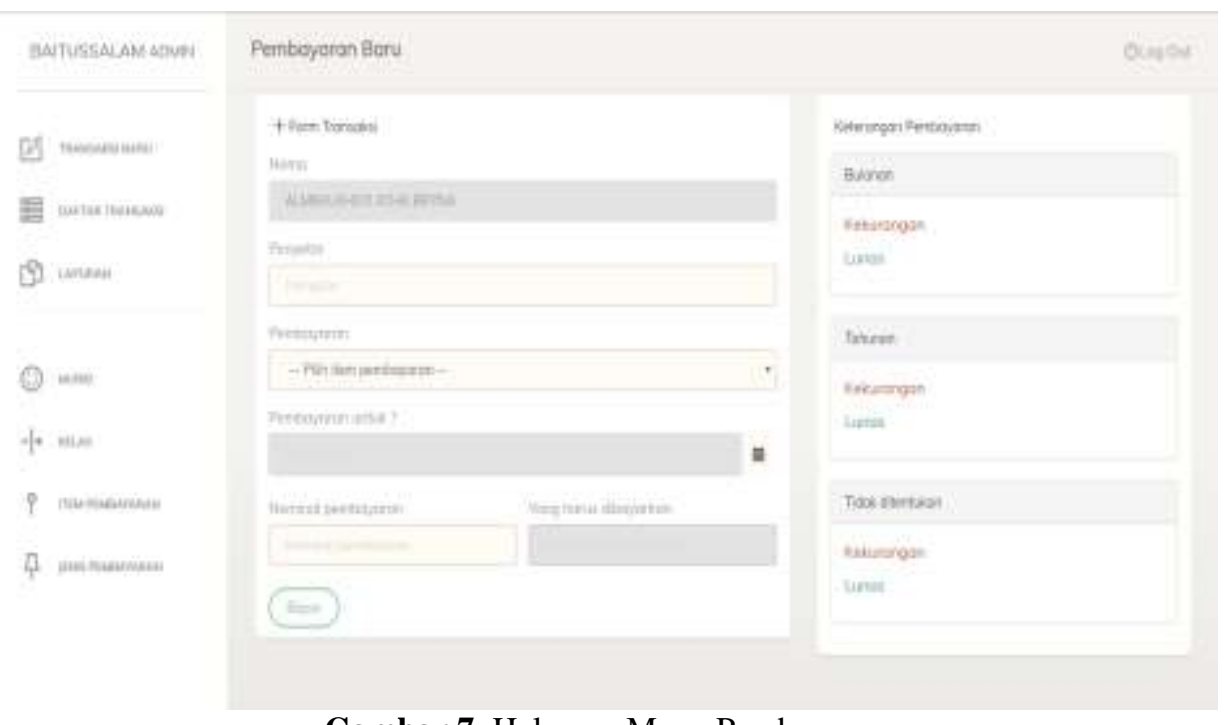

Gambar 7. Halaman Menu Pembayaran

\subsection{Pengujian Sistem}

Tahap terakhir dari perancangan sistem adalah pengujian terhadap sistem itu sendiri. Dalam sistem ini ada dua metode pengujian sistem yaitu black box test dan alpha test.

\begin{tabular}{|l|l|l|l|l|l|}
\hline No. & Pertanyaaan & \multicolumn{4}{|l|}{ Penilaian } \\
\cline { 3 - 6 } & & SS & S & KS & TS \\
\hline 1 & Tampilan sistem mudah dipahami & 2 & 8 & & \\
\hline 2 & Sistem dapat dioprasikan dengan mudah (userfriendly) & 3 & 7 & & \\
\hline 3 & Sistem memudahkan dalam penginputan data murid & & 10 & & \\
\hline 4 & $\begin{array}{l}\text { Sistem memudahkan dalam transaksi pembayaran uang } \\
\text { sekolah }\end{array}$ & 9 & 1 & \\
\hline 5 & Sistem memudahkan dalam mencetak laporan & 2 & 8 & & \\
\hline 6 & $\begin{array}{l}\text { Sistem memudahkan dalam proses pencatatan transaksi } \\
\text { pembayaran }\end{array}$ & 1 & 9 & & \\
\hline
\end{tabular}




\begin{tabular}{|l|l|l|l|l|l|}
\hline 7 & Sistem sudah sesuai dengan kebutuhan & & 7 & 3 & \\
\hline 8 & Sistem yang dibangun bermanfaat dan membantu & 1 & 9 & & \\
\hline Jumlah & 9 & & & \\
\hline
\end{tabular}

Tabel 1. Daftar Pertanyaan dan Penilaian

berdasarkan hasil tersebut, dapat diperoleh prosentase penilaian terhadap sistem, yaitu:

1. Jawaban SS (Sangat Setuju) : $9 / 80 * 100 \%=11.25 \%$

2. Jawaban S (Setuju) : $67 / 80 * 100 \%=83.75 \%$

3. Jawaban KS (Kurang Setuju) : $4 / 80 * 100 \%=5 \%$

4. Jawaban TS (Tidak Setuju) : $0 / 80 * 100 \%=0 \%$

Berdasarkan hasil uji perhitungan tersebut dapat divisualisasikan dalam bentuk grafik berikut:

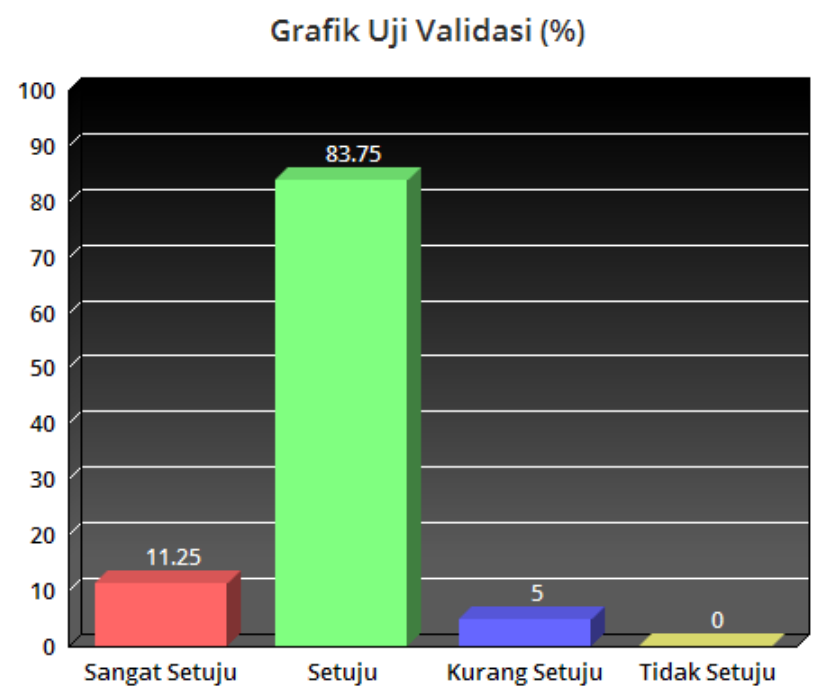

Gambar 8. Grafik Uji Validasi

\section{KESIMPULAN}

Dari pembahasan di dalam penelitian ini yang berjudul Pengembangan Sistem Informasi Keuangan Berbasis Web dapat disimpulkan sebagai berikut:

1. Dengan dibangunnya aplikasi sistem informasi keuangan berbasis web dengan menerapkan konsep MVC mampu menangani proses transaksi pencatatan transaksi pembayaran dan mencetak laporan.

2. Sistem ini dilengkapi dengan fitur tagihan yang membantu dalam proses pengecekkan pembayaran murid lunas atau belum lunas.

3. Hasil pengujian sistem dengan metode Black Box Test menyatakan 100\% sistem sudah berjalan dengan baik dan layak digunakan. Serta dalam pengujian dengan metode Alpha Test, responden yang mengatakan "Sangat Setuju" sebesar $11.25 \%$, yang menyatakan "Setuju" sebesar $83.75 \%$, dan yang menyatakan "Kurang Setuju" sebesar $5 \%$ bahwa sistem yang dibuat sudah berjalan dengan baik dan dapat membantu memberikan informasi pencatatan keuangan serta pelaporan keuangan.

\section{DAFTAR PUSTAKA}

[1] Tenardi, Wendri. dkk. (2013). Sistem Informasi Keuangan pada Sekolah ST. Agatha. Jurnal STMIK, Vol 1.

[2] Wulansari, Nurita. dkk. (2013). Sistem Informasi Pengelolaan Keuangan Sekolah pada Sekolah Menengah Kejuruan (SMK) PGRI 1 Pacitan. IJNS, Vol 10 No 2. 
[3] Kadir, Abdul. (2014). Pengenalan Sistem Informasi. Yogyakarta: ANDI.

[4] Daqiqil Id, M. Ti, Ibnu. (2011). Framework Codeigniter. Pekanbaru: s.n.

[5] Simarmata, Janner dan Paryudi, Iman. (2010). Basis Data. Yogyakarta: ANDI. 